\title{
PERBANDINGAN PENGGUNAAN MULTIMEDIA SECARA TUTORIAL DAN PRESENTASI TERHADAP PENGUASAAN KONSEP DAN KETERAMPILAN PROSES SAINS PADA KONSEP SISTEM PERTAHANAN TUBUH
}

\author{
Eni Nuraeni (eni.bio_upi@yahoo.com) \\ Jurusan Pendidikan Biologi FPMIPA UPI \\ Dadang Machmudin \\ Tenten Hermansyah
}

\begin{abstract}
The purpose of this study was to compare the use of multimedia in the presentation and tutorial of mastery of the concept and process skills in science concerning the immune system. The experimental study was designed with Quasy pre-test post-test, multiple nonequivalent group design. Two treatments for each tutorials and presentations class were employed. Instruments consist of basic concept mastery test, the concept and process skills, questionnaires, and interviews. The result showed that there were differences among the two classes. However, there was no significant difference students' process skill in science. Communication skills measured showed no significant difference, while the predictive ability measured showed a significant difference.
\end{abstract}

Keywords: mastery of concepts, science process skills

\begin{abstract}
ABSTRAK
Tujuan penelitian ini adalah membandingkan penggunaan multimedia secara presentasi terhadap penguasaan konsep dan KPS pada konsep sistem pertahanan tubuh melalui penggunaan multimedia secara tutorial dan presentasi. Penelitian ini merupakan Quasy eksperiment dengan desain pre-test post-test, nonequivalent multiple group design. Digunakan dua kelas perlakuan masing-masing untuk kelas tutorial dan presentasi. Instrumen yang digunakan meliputi pokok uji penguasaan konsep, pokok uji KPS, angket dan wawancara. Hasi menunjukan adanya perbedaan penguasaan konsep pada kedua kelas perlakuan. Akan tetapi perlakuan yang diberikan tidak menunjukan adanya perbedaan terhadap KPS siswa. Kemampuan komunikasi yang diukur menunjukan tidak adanya, sedangkan kemampuan prediksi yang diukur menunjukan adanya perbedaan yang signifikan.
\end{abstract}

Kata kunci: keterampilan proses sains, multimedia, penguasaan konsep, presentasi, tutorial

Seiring dengan perkembangan ilmu pengetahuan dan teknologi, kebutuhan siswa dalam pembelajaran semakin meningkat. Siswa membutuhkan akses terhadap guru ndicator al, waktu kelas yang memadai, pemenuhan material belajar, penyediaan ruang kerja, dan sumber-sumber belajar yang mereka butuhkan di sekitar mereka (McLaughlin \& Arbeider, 2008). Siswa membutuhkan akses 
tersebut agar mereka mendapatkan pengalaman belajar yang lebih bermakna, sehingga perlu adanya pemenuhan terhadap kebutuhan siswa tersebut.

Menurut Rustaman et al. (2003) pengalaman belajar siswa akan semakin bermakna jika siswa aktif untuk mengamati suatu hal. Dengan demikian siswa dapat menemukan persamaan atau perbedaan dari hasil pengamatan tersebut, sehingga siswa dapat mengelompokan dan mengkomunikasikan hasilnya. Berdasarkan hal tersebut aspek proses perlu diperhatikan, dan pengamatan merupakan salah satu dari keterampilan proses sains (KPS), begitu pula keterampilan mengelompokan dan mengkomunikasikan. Oleh karena itu KPS diperlukan dalam mengembangkan aspek proses dalam pembelajaran. Dengan demikian hasilnya dapat digunakan untuk membantu siswa dalam kebermaknaan belajar.

Pengembangan proses pembelajaran dilakukan untuk memenuhi kebutuhan-kebutuhan siswa yang beragam. Akan tetapi keragaman kebutuhan siswa tersebut sulit dipenuhi secara keseluruhan. Oleh karena itu diperlukan sebuah format yang mampu memenuhi keberagaman tersebut. Menurut Reeds (2006), terdapat suatu format yang dapat memperkaya lingkungan belajar dengan menampilkan informasi melalui berbagai variasi penyampaian. Format tersebut adalah multimedia.

Metode pengajaran dengan menggunakan komputer sebagai tutor dapat menambah jumlah "guru" di dalam kelas (Newby et al., 2006). Dengan demikian seorang guru dapat memperluas perhatiannya terhadap pembelajaran di dalam kelas dengan bantuan multimedia, sehingga kebutuhan setiap siswa terhadap guru professional dapat dipenuhi.

Menurut Munir (2009), penggunaan teknologi informasi dapat mengatasi keterbatasan ruang dan waktu. Penerapannya terhadap multimedia secara individual dapat menyediakan waktu kelas yang memadai dan ruang kerja untuk siswa. Hal tersebut dikarenakan pada metode ini siswa dapat belajar sesuai dengan kecepatan belajarnya. Oleh karena itu dapat memfasilitasi kecepatan belajar siswa yang berbeda pada kelas yang sama. Siswa secara aktif memperoleh pengetahuan sesuai tuntutan kurikulum. Hal tersebut dikarenakan multimedia yang digunakan disusun untuk memfasilitasi proses belajar secara aktif.

Siswa membutuhkan sumber-sumber dan material belajar, dan siswa diharapkan mendapat kesempatan yang sama dalam memperoleh sumber dan material belajar. Akan tetapi setiap siswa memiliki gaya belajar yang berbeda dalam memperoleh informasi. Green dan Brown (2002), mendefinisikan bahwa multimedia dapat dikatakan suatu metode penyampaian informasi dengan menggunakan dua atau lebih variasi yang meliputi grafik (gambar dua dimensi), audio, text dan interaktivitas (komponen navigasi pada suatu program komputer). Menurut Newby et al. (2006), grafik dan pengembangannya seperti animasi, video, dan tipe visual lainnya dapat mengakomodasi siswa dengan gaya belajar visual. Siswa auditori dapat diakomodasi gaya belajarnya dengan menggunakan komponen audio pada multimedia. Sedangkan siswa dengan gaya belajar kinestetik dapat diakomodasi dengan adanya komponen interaktivitas pada multimedia.

Secara umum penggunaan komputer sebagai tutor berpotensi terhadap hasil belajar yang lebih baik. Hal tersebut dikarenakan siswa dapat secara aktif mencari pengetahuan. Akan tetapi sebuah penelitian yang dilakukan pada praktikum komputer (Tosun et al., 2006), menyatakan bahwa respon siswa terhadap pembelajaran dengan menggunakan komputer secara individual tidak lebih baik dibandingkan melalui guru sebagai penyampai materi. Penelitian-penelitian yang telah dilakukan pada konsep-konsep abstrak melalui penggunaan produk Interactive Computer Technology (ICT) secara presentasi pun memberikan hasil yang baik (Putra, 2007; Wulandari, 2009; 
Yoanita, 2009). Namun hal tersebut tidak menutup kemungkinan hasilnya berbanding terbalik pada materi sistem pertahanan tubuh.

Sistem pertahanan tubuh membahas mekanisme pertahanan tubuh terhadap zat asing. Akan tetapi mekanisme tersebut sulit diamati dengan menggunakan peralatan yang sederhana. Oleh karena itu dengan menggunakan multimedia proses tersebut dapat disampaikan kepada siswa dengan mudah, sehingga konsep dari mekanisme sistem pertahanan tubuh dapat disampaikan kepada siswa.

Penggunaan multimedia tidak hanya dapat digunakan dalam meningkatkan penguasaan konsep. Newby et al. (2006), mengemukakan bahwa penggunaan multimedia dapat digunakan dalam mengajarkan keterampilan yang lebih tinggi. Senada dengan pernyataan tersebut, Nuraeni (2006) mengemukakan bahwa penggunaan multimedia interaktif dapat meningkatkan kemampuan inkuiri siswa secara signifikan. Kemampuan inkuiri yang dimaksud di antaranya keterampilan berhipothesis, interpretasi, prediksi, merencanakan percobaan, bertanya dan berkomunikasi. Kemampuan inkuiri yang dimaksud tersebut termasuk juga ndicator dari keterampilan proses sains.

Tujuan dari penelitian ini adalah untuk membandingkan penggunaan multimedia terhadap penguasaan konsep dan KPS pada konsep sistem pertahanan tubuh secara tutorial dan presentasi.

\section{METODOLOGI}

Metode penelitian yang digunakan yaitu Quasy Eksperiment. Desain yang digunakan yaitu pre-test post-test, nonequivalent multiple group design (Wiersma, 1995). Pada penelitian ini digunakan dua kelas eksperimen, yaitu kelas dengan penggunaan multimedia secara tutorial dan secara presentasi.Sampel dalam penelitian ini adalah siswa SMA Cisarua Bandung kelas XI yang terdiri dari dua kelas eksperimen. Kedua kelas perlakuan memiliki jumlah sampel yang sama, yaitu 20 orang. Instrumen yang digunakan dalam penelitian ini di antaranya pokok uji penguasaan konsep, pokok uji KPS, angket, wawancara

\section{HASIL DAN PEMBAHASAN}

Berdasarkan data yang dihimpun diperoleh informasi bahwa penguasaan konsep pada kedua kelas perlakuan secara signifikan berbeda. Data yang diperoleh dari kedua kelas perlakuan berasal dari jumlah sampel yang sama. Pengujian terhadap pre-test menunjukan bahwa data kedua kelas tersebut tidak berbeda signifikan. Oleh karena itu informasi yang menunjukan perbandingan antara kedua kelas perlakuan diperoleh dari data posttest.

Rekapitulasi nilai pre-test dan post-test pada kelas eksperimen 1 (Tutorial) dan kelas eksperimen 2 (presentasi) dapat dilihat pada Tabel 1.

Tabel 1. Rekapitulasi Pengujian Statistik Nilai Penguasaan Konsep Kelas Eksperimen 1 (Tutorial) dan Kelas Eksperimen 2 (Presentasi)

\begin{tabular}{crrrr}
\hline \multirow{2}{*}{ Komponen } & \multicolumn{2}{c}{ Pre-test } & \multicolumn{2}{c}{ Post-test } \\
\cline { 2 - 5 } & Tutorial & Presentasi & Tutorial & Presentasi \\
\hline $\mathbf{n}$ & 20 & 20 & 20 & 20 \\
$\mathbf{X}$ & 28,33 & 31,33 & 79,33 & 68,33 \\
SD & 10,34 & 11,46 & 17,02 & 12,01 \\
\hline Nilai Tertinggi & 53,33 & 60,00 & 100,00 & 100,00 \\
\hline Nilai Terendah & 13,33 & 13,33 & 33,00 & 46,67 \\
\hline
\end{tabular}


Tabel 1. Lanjutan

\begin{tabular}{|c|c|c|c|}
\hline \multirow{3}{*}{$\begin{array}{c}\text { Uji Homogenitas } \\
F_{\text {tabel (a:0,05) }} \\
\text { F hitung } \\
\end{array}$} & \multicolumn{3}{|c|}{$\begin{array}{c}\text { Uji Homogenitas } \\
\text { (Asumsi varians homogen diterima untuk } F \text { hitung }<F \text { tabel) }\end{array}$} \\
\hline & \multirow{2}{*}{$\begin{array}{l}2,53 \\
1,23\end{array}$} & \multicolumn{2}{|c|}{2,53} \\
\hline & & & \\
\hline Kesimpulan & Homogen & \multicolumn{2}{|c|}{ Homogen } \\
\hline Uji Normalitas & \multicolumn{3}{|c|}{$\begin{array}{c}\text { Uji Normalitas } \\
\text { (Distribusi normal untuk D hitung < D tabael) }\end{array}$} \\
\hline$D_{\text {tabel }}(\mathrm{a}: 0,05)$ & $0,294 \quad 0,294$ & 0,294 & 0,294 \\
\hline Dhitung & 0,207 & 0,213 & 0,175 \\
\hline Kesimpulan & Normal & Normal & Normal \\
\hline Uji Hipotesis & $\begin{array}{c}\text { Uji t } \\
\text { terima } \mathrm{H}_{1} \text { apabila thitung } \\
\text { tidak berada di daerah } x \\
(- \text { trabel }<x<+ \text { tabel })\end{array}$ & \multicolumn{2}{|c|}{$\begin{array}{c}\text { Uji t } \\
\text { terima } \mathrm{H}_{1} \text { apabila thitung } \\
\text { tidak berada di daerah } x \\
\left(- \text { trabel }^{\prime}<x<+ \text { trabel }\right)\end{array}$} \\
\hline $\mathrm{T}_{\text {tabel }} / \bigcup_{\text {tabel }(\mathrm{a}: 0,05)}$ & 2,02 & \multicolumn{2}{|c|}{2,02} \\
\hline$T_{\text {hitung }} / U_{\text {hitung }}$ & $-0,869$ & \multirow{2}{*}{\multicolumn{2}{|c|}{$\frac{2,361}{\mathrm{H}_{1} \text { diterima }}$}} \\
\hline Kesimpulan & $\mathrm{H}_{1}$ ditolak & & \\
\hline
\end{tabular}

Pengujian terhadap post-test yang dilakukan menunjukan bahwa data post-test pada kedua kelas perlakuan berbeda signifikan.

Perbedaan hasil penguasaan konsep tersebut dapat dilihat perbandingannya pada Gambar 1. Pada gambar tersebut ditunjukan bahwa penguasaan konsep pada kedua kelas perlakuan diketahui mengalami peningkatan. Rata-rata nilai post-test pada kelas tutorial lebih tinggi dibandingkan rata-rata kelas presentasi. Artinya bahwa penggunaan multimedia secara tutorial memberikan hasil yang lebih baik dibandingkan metode presentasi terhadap penguasaan konsep sistem pertahanan tubuh.

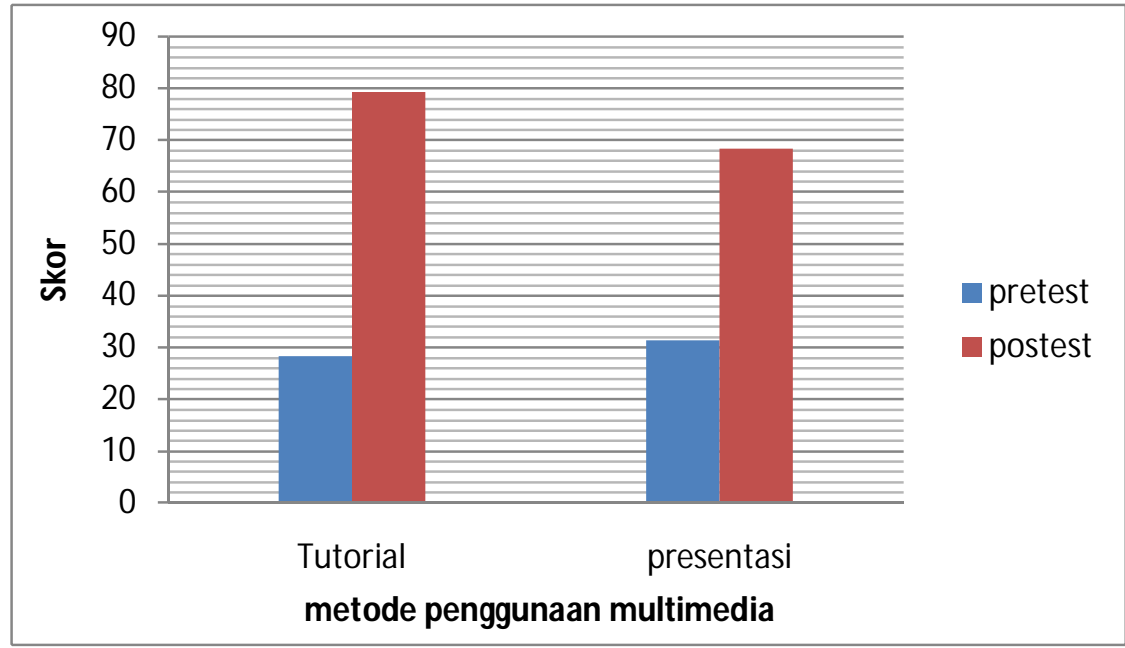

Gambar 1. Perbandingan rata-rata hasil pre-test dan post-test penguasaan konsep pada kelas tutorial dan presentasi. 
Banyak faktor yang memungkinkan hal tersebut dapat terjadi, di antaranya adalah faktor pengalaman belajar dan pemenuhan terhadap kebutuhan belajarsiswa. Aspek motivasi yang timbul dalam pembelajaran turutmempengaruhi hasil belajar.

Dahar (1996) mengemukakan bahwa konsep-konsep yang dimiliki seseorang akan terbentuk melalui pengalaman-pengalaman. Ketika seorang anak dihadapkan oleh stimulus-stimulus lingkungan (objek, proses, peristiwa, atau fenomena lainnya), maka akan timbul abstraksi mengenai stimulus-stimulus tersebut, sehingga ciri-ciri dari stimulus tersebut dikenal oleh anak Dengan demikian suatu abstraksi atau konsep akan dimiliki seorang anak karena telah mengenal ciri-ciri konsep tersebut berdasarkan pengalamannya.

Motivasi dapat diperoleh karena pengalaman belajar yang diberikan merupakan hal yang baru bagi siswa. Hasil angket menunjukan bahwa seluruh siswa pada kelas tutorial menyatakan bahwa pembelajaran yang dilakukan merupakan hal yang baru bagi mereka. Akan tetapi sebagian besar (75\%) siswa pada kelas presentasi tidak menyatakan demikian. Dengan demikian dapat dikatakan bahwa penggunaan metode tutorial akan lebih memotivasi minat belajar siswa dibandingkan melalui metode presentasi. Angket yang diberikan menunjukan bahwa metode tutorial dapat dikatakan lebih menyenangkan dibandingkan presentasi. Sebagian besar siswa (85\%) pada kelas tutorial menyatakan bahwa pembelajaran yang dilakukan menyenangkan, sedangkan pada kelas presentasi respon menyenangkan tersebut rebih rendah dibandingkan kelas tutorial (60\%).

Newby et al. (2006), menyatakan bahwa tutorial menyediakan instruksi individual yang optimal. Semua siswa mendapatkan perhatian individu yang mereka butuhkan, sehingga menyediakan partisipasi tingkat tertinggi siswa. Penggunaan tutorial melalui komputer dapat mengatasi tingkat perkembangan siswa. Siswa yang belajar lambat akan belajar sesuai kecepatan belajarnya. Siswa tersebut dapat mengulang kembali proses tertentu dalam pembelajaran hingga mengerti. Akan tetapi tidak demikian pada kelas presentasi. Berdasarkan angket yang diberikan diketahui bahwa siswa kelas presentasi merasa kesulitan mengikuti penjelasan dari guru. Sebagian besar siswa kelas presentasi (60\%) menyatakan bahwa penjelasan guru sulit untuk diikuti. Hal tersebut mungkin saja menjadi faktor yang menyebabkan penguasaan konsep pada kelas presentasi lebih rendah dibandingkan pada kelas tutorial.

Gambar 2, merupakan salah satu screen multimedia yang menunjukan aspek interaktifitas kepada siswa, pada bagian kanan tersedia hyperlink menuju sub konsep pada sistem pertahanan tubuh. Bagian kiri berisi materi-materi pendalaman terhadap sub konsep tertentu. Hal ini memungkinkan pengguna memiliki kebebasan dan berperan aktif dalam menentukan pilihan untuk membuka materi. Siswa dapat memilih materi yang mereka butuhkan,sehingga siswa dapat menyesuaikan kecepatan belajarnya. Siswa yang belajar dengan cepat dapat mempercepat proses belajarnya, sedangkan siswa yang lambat dapat menyesuaikan kecepatan belajar melalui pengulangan yang dapat dilakukan sesuai keinginannya.

Tabel 2 menunjukan rekapitulasi nilai KPS siswa. Rata-rata gain KPS pada kelas tutorial sebesar 9,37 $\pm 10,41$ dan pada kelas presentasi sebesar $26,75 \pm 11,95$. Hal tersebut menunjukan bahwa rata-rata gain pada kelas presentasi lebih besar dibandingkan kelas tutorial.

Berdasarkan Tabel 2 diketahui bahwa KPS pada kedua kelas perlakuan berbeda signifikan. Rata-rata hasil pre-test KPS kelas tutorial lebih besar dibandingkan kelas presentasi. Demikian pula dengan post-test, rata-rata penguasaan KPS siswa kelas tutorial lebih besar dibandingkan kelas presentasi. Akan tetapi Gain KPS kelas presentasi lebih besar dibandingkan kelas tutorial. 


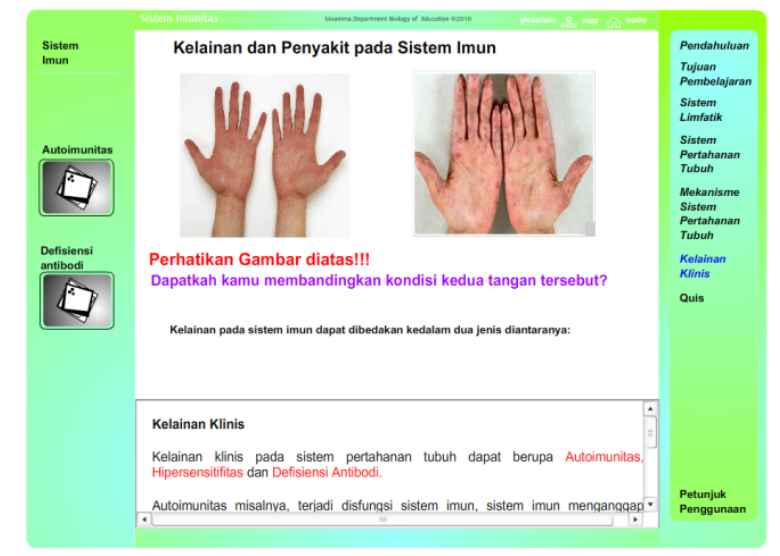

Gambar 2. Screen Multimedia yang menunjukan aspek interaktifitas

Peran guru dalam hal ini diduga sangat berpengaruh terhadap peningkatan KPS siswa di kelas presentasi. Semiawan (1987) mengemukakan bahwa setiap siswa sudah memiliki potensi untuk memroses informasi. Tugas guru dalam hal ini adalah untuk membangkitkan potensi tersebut Selanjutnya dikemukakan bahwa tugas guru tidak hanya memberikan pengetahuan, melainkan menyiapkan situasi yang menggiring anak untuk bertanya, mengamati, mengadakan eksperimen, serta menemukan fakta dan konsep sendiri.

Penggunaan multimedia tidak hanya efektif untuk mengembangkan penguasaan konsep saja. Akan tetapi dapat digunakan untuk keterampilan yang lebih tinggi. Nuraeni (2006), mengemukakan bahwa penggunaan multimedia interaktif mampu meningkatkan kemampuan inkuiri. Keterampilan inkuiri tersebut di antaranya meliputi keterampilan komunikasi dan menerapkan konsep. Oleh karena itu penggunaan multimedia memungkinkan untuk mengembangkan KPS yaitu keterampilan komunikasi dan menerapkan konsep.

Penggunaan multimedia dapat dilakukan secara mandiri oleh siswa di dalam kelas. Warsita (2006), mengemukakan bahwa multimedia memiliki keterbatasan intelegen. Tingkat intelegen multimedia hanya sebatas program yang ditanamkan. Guru selain berperan sebagai penyampai materi, berperan pula sebagai pembimbing, dan pengelola pembelajaran. Meskipun aplikasi multimedia dapat dikondisikan untuk memiliki peran tersebut. Metode tutorial memiliki kelebihan dalam hal tingginya tingkat interaktifitas siswa. Metode ini juga menyediakan instruksi individual yang optimal dan mampu meningkatkan minat belajar siswa. Dengan demikian metode ini cocok digunakan terhadap pembelajaran secara individual. Metode presentasi cocok digunakan untuk menangani jumlah siswa yang banyak, sehingga memungkinkan siswa untuk mendapatkan informasi yang sama. Peran guru pada metode presentasi juga memberikan pengaruh yang baik terhadap proses pembelajaran (Newby et al., 2006). Dengan demikian kedua metode yang digunakan berpotensi memberikan kesempatan belajar yang baik kepada siswa.

Aspek guru dalam kelas presentasi memang menjadi nilai tambah, akan tetapi pada umumnya siswa kurang termotivasi dengan metode ini.. Sebagian besar (60\%) siswa merasa kesulitan untuk mengikuti penjelasan dari guru. Hal ini berpengaruh terhadap hasil belajar karena materi yang diberikan kepada siswa tidak tersampaikan. 
Tabel 2. Rekapitulasi Nilai Keterampilan Proses Sains pada Kelas Tutorial dan Presentasi

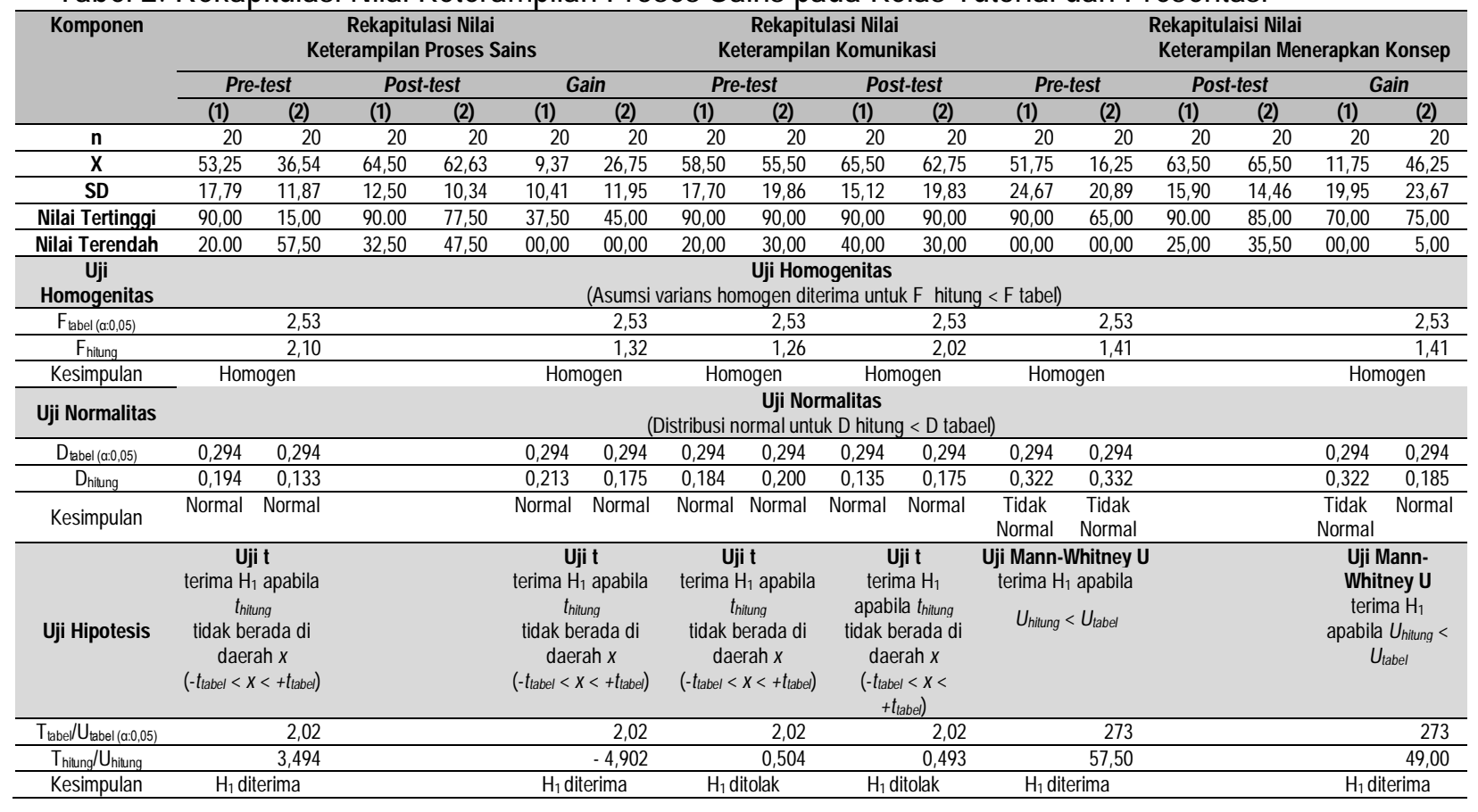

Keterangan :

(1) : Kelas tutorial

(2) : Kelas presentasi

$\mathrm{n}$ : Jumlah siswa

$X$ : Rata-rata

SD : Standar deviasi

Data dalam Tabel 2 menunjukan bahwa keterampilan komunikasi pada kedua kelas tersebut tidak berbeda siginifikan. Secara umum kedua kelas perlakuan menunjukan peningkatan terhadap keterampilan berkomunikasi.

Menurut Abruscato (Ulfa, 2007) berkomunikasi adalah menyampaikan hasil pengamatan yang berhasil dikumpulkan atau menyampaikan hasil penyelidikan. Keterampilan mengkomunikasikan ini dapat dikembangkan dengan menyajikan informasi dari grafik atau gambar yang menjelaskan benda-benda atau kejadian-kejadian secara rinci. Multimedia berpotensi mengembangkan keterampilan KPS. Hal tersebut dikarenakan multimedia mampu menghimpun informasi dari grafik atau gambar yang menjelaskan benda-benda atau kejadian-kejadian secara rinci. Multimedia juga dapat menyampaikan hasil pengamatan yang lebih komunikatif melaui penggunaan teks dan gambar serta video ataupun animasi. Keterampilan komunikasi dilatih melalui keterampilan mengubah suatu bentuk penyajian ke dalam penyajian lain. Siswa juga diberikan pelatihan komunikasi dalam menjelaskan data penelitian dan bagan dalam multimedia yang disajikan.

Gambar 3 menunjukan salah satu screen pelatihan terhadap keterampilan komunikasi. Pada kelas presentasi guru membimbing siswa dalam setiap langkah pelatihannya, sedangkan pada kelas tutorial siswa dapat dengan cermat memperhatikan maksud yang ditunjukan gambar pada screen berikut. 


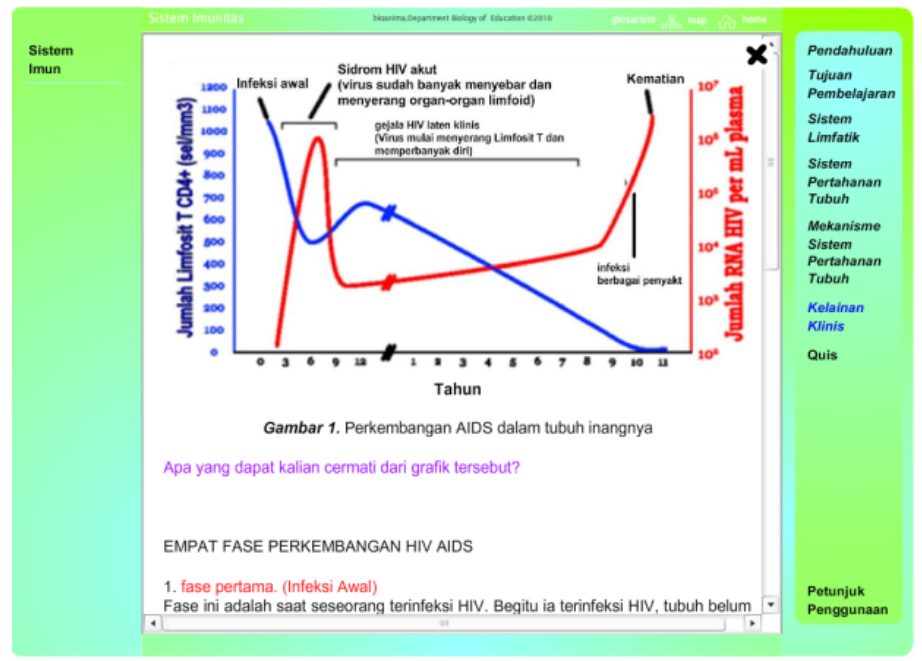

Gambar 3 Screen untuk melatih kemampuan komunikasi siswa.

Newby et al. (2006) mengemukakan bahwa dengan adanya bantuan multimedia secara presentasi, setiap siswa akan mendapatkan informasi yang sama. Kemungkinannya adalah peningkatan hasil belajar yang dimaksud akan terwujud secara merata. Guru dapat memberikan penekanan terhadap bagian penting yang ingin disampaikan,

Tabel 2 menunjukan bahwa gain keterampilan menerapkan konsep kedua kelas berbeda signifikan. Keterampilan menerapkan konsep dapat dikembangkan dengan memberikan siswa polapola hasil pengamatan, sehingga dirangsang untuk mengemukakan kemungkinan yang terjadi pada keadaan yang belum diamati (Rustaman et al., 2003). Dibandingkan penjelasan secara presentasi, metode tutorial memiliki kelebihan memfasilitasi tingkat kecepatan belajar siswa. Siswa pada kelas tutorial dapat mengulang kembali dan mencermati materi dengan waktu yang sesuai untuk mereka, sehingga pola-pola hasil pengamatan untuk merangsang kemampuan menerapkan konsep lebih mudah dipahami.

Menerapkan konsep dapat dilatih dengan meminta siswa mengemukakan konsep yang telah dipelajari dalam situasi baru (Rustaman et al., 2003). Guru pada kelas presentasi mengemukakan pola-pola tersebut dan mengaitkannya pada kehidupan sehari-hari. Cara seperti ini sangat menarik perhatian siswa. Cara yang ditempuh guru di antaranya adalah dengan menjelaskan pola-pola hasil penelitian terkait pembahasan memori immunologi. Selanjutnya guru memberikan topik tentang penyakit cacar yang tidak mungkin menyerang untuk kedua kalinya. Guru meminta siswa untuk mengaitkan kasus penyakit cacar tersebut terhadap konsep memori immunologi yang telah dipelajari. Selanjutnya guru memberikan pertanyaan agar siswa dapat menerapkan konsep yang dipelajari pada kondisi baru. Hal-hal tersebut merupakan salah satu faktor meningkatnya keterampilan menerapkan konsep pada kelas presentasi. Gain pada kelas presentasi meningkat Hal ini sejalan dengan penelitian Nuraeni (2006), yang menerangkan keterampilan menerapkan konsep siswa mengalami peningkatan yang signifikan melalui penggunaan multimedia interaktif yang dipresentasikan. 


\section{KESIMPULAN DAN SARAN}

Penguasaan konsep sistem pertahanan tubuh siswa dinyatakan berbeda signifikan antara kelas tutorial dan presentasi. Hasilnya menunjukan bahwa penguasaan konsep siswa kelas tutorial lebih tinggi dibandingkan kelas presentasi. Perlakuan yang diberikan juga menunjukan adanya perbedaan signifikan terhadap keterampilan proses sains. Rata-rata gain yang diperoleh pada kelas presentasi lebih besar dibandingkan rata-rata gain pada kelas tutorial. Kemampuan komunikasi yang diukur menunjukan tidak adanya perbedaan pada kedua kelas tersebut. Lain halnya dengan keterampilan menerapkan konsep, pada keterampilan ini uji statistik menunjukan adanya perbedaan yang signifikan. Perbedaannya terletak pada gain kedua kelas tersebut. Gain keterampilan prediksi pada kelas presentasi lebih tinggi dibandingkan pada kelas tutorial. Respon yang diberikan siswa pada umumnya positif pada kedua kelas perlakuan. Meskipun demikian respon positif terhadap metode tutorial lebih tinggi dibandingkan dengan metode presentasi

\section{REFERENSI}

Dahar, R.W. (1996). Teori-teori belajar. Jakarta: Erlangga.

Green \& Brown. (2002). Multimedia project in the classroom: A guide to development and evaluation. Thousand Oaks California: Corwin Press Inc.

McLaughlin, J., \& Arbeider, D. A. (2008). Evaluating multimedia-learning tools based on authentic research data that teach biology concepts and environmental stewardship. Contemporary issues in tand teacher education, 8(1). Diambil 4 Juli 2010, dari http://www.citejournal.org/vol8/iss1/ science/article1.cfm.

Newby., Stepich, \& Russel. (2006). Educational technology for teaching andl. Ohio: Pearson Merrill Prentice Hall.

Nuraeni (2006). Pengembangan media pembelajaran genetika mikroba berbantuan komputer untuk meningkatkan penguasaan konsep, kemampuan inkuiri dan sikap mahasiswa. Tesis Master yang tidak dipublikasikan, Universitas Pendidikan Indonesia, Bandung.

Munir. (2009). Konstribusi teknoligi informasi dan komunikasi TIK dalam pendidikan di era globalosasi pendidikan Indonesia. Jurnal PTIK, 2(2), 1-4.

Putra. (2007). Pengaruh penggunaan softwere presentasi terhadap hasil belajar pada konsep sistem reproduksi. Rustaman, N. et. al. 2003. Strategi belajar mengajar biologi. Bandung: FPMIPAUPI.

Rustaman, Dirjosoemarto, Yudianto, Achmad, Subekti., \& Rochintaniawati, et al. (2003). Strategi belajar mengajar Biologi. Bandung: FPMIPA-UPI.

Semiawan. (1987). Pendekatan keterampilan proses. Jakarta: PT Gramedia.

Tosun., Suczus, \& Yigit. (2006). "The effect of computer assisted and computer based teaching methods on computer course success and computer using attitudes of students". The Turkish Online Journal of Educational Technology, 5(3), 46-53.

Ulfa. (2007). Penerapan keterampilan proses dalam pembelajaran IPA di sekolah dasar. Surabaya: Surabaya Intelectual Club.

Warsita. (2008). Teknologi pembelajaran. Jakarta Rineka Cipta.

Widodo. (2009). Gambaran penelitian pendidikan biologi: Perkembangan penelitian di jurusan pendidikan biologi FPMIPA UPI. ASIMILASI: Jurnal pendidikan Biologi, 1(1), 54-61.

Wiersma. (1995). Research methods in education an introduction. Massachussetts: A Simon and Schuster Company. 
Wulandari. (2009). Pembelajaran biologi dengan menggunakan media animasi untuk meningkatkan hasil belajar siswa, (Suatu penelitian tindakan kelas di kelas VII A SMP Negeri A SMPN 29 Bandung pada konsep sistem peredaran darah manusia). Skripsi sarjana yang tidak dipublikasikan, Universitras Pendidikan Indonesia, Bandung.

Yoanita. (2009). Pengaruh penggunaan media animasi computer terhadap keterampilan berpikir kritis siswa SMA pada pembelajaran sistem reproduksi manusia. Skripsi sarjana yang tidak dipublikasikan, Universitras Pendidikan Indonesia, Bandung. 